DOI: 10.17707/AgricultForest.61.3.07

Segun O. OLADELE ${ }^{1}$

\title{
MYCORRHIZAL FUNGUS (GLOMUS MOSSAE) INOCULATION EFFECTS ON PERFORMANCE AND ROOT BIOMASS DEVELOPMENT OF CACAO SEEDLINGS IN THE NURSERY
}

\begin{abstract}
SUMMARY
Inoculation of young cacao seedlings during the early stage of development with efficient arbuscular mycorrhizae fungi (AMF) strain provides several benefits that enhances optimum establishment in fields after transplanting from nursery. A field nursery experiment was conducted to evaluate the responsiveness of cacao $\left(\mathrm{F}_{3}\right.$ amazon variety) seedlings to different levels of arbuscular mycorrhizae (Glomus mossae) inoculation in a potting medium. Parameters taken at termination of the experiment includes; plant height, leaf number, stem girth, leaf area, shoot and root fresh weight and dry weight, mycorrhizal dependency (MD) and growth response to arbuscular mycorrhiza (AM) fungi inoculation. Result from the study showed that AM fungi inoculated seedlings at level of $50 \mathrm{~g}$ and $100 \mathrm{~g}$ exhibited better transplant performance due to its higher plant height $(34.24$ and $37.89 \mathrm{~cm})$, higher leaf number $(11.70$ and $12.67)$, higher stem girth $(0.67 \mathrm{~mm}$ and $0.75 \mathrm{~mm})$, higher leaf area $\left(51.38 \mathrm{~cm}^{2}\right.$ and $\left.59.45 \mathrm{~cm}^{2}\right)$,higher shoot fresh weight $(7.42 \mathrm{~g}$ and $9.98 \mathrm{~g})$, higher root fresh weight $(6.48 \mathrm{~g}$ and $6.77 \mathrm{~g})$, higher shoot dry weight $(3.17 \mathrm{~g}$ and $3.88 \mathrm{~g})$, higher root dry weight (1.17 and $1.21 \mathrm{~g})$ and higher fresh root/shoot ratio (0.87 and 0.69). While application of mycorrhizae at $50 \mathrm{~g}$ level, recorded the highest level of Glomus mossae colonization (81.4\%).
\end{abstract}

Keywords: Arbuscular mycorrhizae, Glomus mossae, Cacao seedlings, Nursery.

\section{INTRODUCTION}

Cacao (Theobroma cacao) is a native of amazon region in South-America, but the bulk of it is produced in the tropical areas of the African continent [1]. Nigeria is the fourth-largest producer of cacao in the world behind Cote d'ivoire, Ghana and Indonesia. Cacao is the country's most important agricultural export due to the significant amount of foreign exchange earnings accruing to the country. Despite its importance in the years before independence and after, the sector declined after the oil boom of the 1970s and suffered years of neglect. The neglect was attributed to several constraints faced by farmers (bulks of whom are peasant and small-holder farmers) which are; limited access to improved production technologies and practices, inadequate access to inputs and subsidies,

\footnotetext{
1 Segun O. Oladele (corresponding author: segun.oladele@aaua.edu.ng), Adekunle Ajasin University, Department of Agronomy, P.M.B 01, Akungba-Akoko, Ondo State NIGERIA.

Note: The authors declare that they have no conflicts of interest. Authorship Form signed online.
} 
lack of proper marketing channels, unsatisfactory quality standards, below average percentage seedling establishment post transplanting, aged cacao farms, high cost and scarcity of high yielding hybrid seedlings [5]; [11]. In an effort to achieve increased production, economic return for farmers and foreign exchange in Nigeria, a number of initiatives were introduced. Among such is the presidential initiative on cacao production sustainability and rehabilitation pronounced by the Federal Government of Nigeria in 1999, the major aim was to revive the old glory of cacao through production practices with the Nursery stage a focal point and make it an engine of Nigerian economy [2]. To realize these initiatives, an efficient and alternate means of growing cacao seedlings at a low cost which will lead to an excellent percentage establishment on the field after transplanting giving the poor purchasing capacity of farmers need to be considered. It is of utmost importance that cacao need to pass through a nursery stage to allow for easy and good establishment on the field [3]. This led to the use of external chemical nutrient sources to supplement that in the potting medium. However, according to [20] the use of fertilizers like NPK in cacao nursery has led to high transplanting shock when transplanted, leading to poor survival rate on the field and yield loss. These findings spurred researchers to exploit other nutrient sources for potting medium, which presented an excellent opportunity for Arbuscular mycorrhizal fungi (AMF) to be incorporated in cacao nursery production systems as it help reduce fertilizer and pesticide usage, and enhance crop vigor, productivity, and plant survival rates during transplanting to field conditions. Arbuscular mycorrhizal fungi (AMF) are obligatory biotrophic symbionts occurring in nearly all natural and agricultural soils and commonly colonize roots of many plant species [19]. The primary effect of AMF on their host plant is an increase in plant growth and nutrient uptake [12]. Plants with mycorrhizae are potentially more effective at nutrient and water acquisition [9] and less susceptible to disease [14]. They can increase plant uptake of nutrients especially relatively immobile elements such as $\mathrm{P}, \mathrm{Zn}$ and $\mathrm{Cu}$ [16] and consequently, increase root and shoot biomass and improve plant growth. Therefore, successful inoculation of nursery crops with AMF for nutrient, water and disease management will guarantee better establishment rate and vegetative growth after transplanting. The study was carried out in a field nursery using (polythene pot) to assess the performance of cacao seedlings with respect to different levels of inoculation with arbuscular mycorrhizae fungi with a view to select appropriate rate of inoculation for exploitation by small holder farmers for quality production of cacao seedlings prior to transplanting.

\section{MATERIAL AND METHODS}

\section{Description of Location and Experimental Site}

The study was carried out on a nursery site at the Teaching and Research farm of the Federal university of technology, Akure Ondo state, Nigeria (from mid-December to mid-March 2010). It is located between latitude $5^{\circ}, 08$ ' $10.5^{\prime}$ ' $\mathrm{E}$ 
and $7^{\circ} 17^{\prime} 59.2^{\prime} ' \mathrm{~N}$, at elevation of $140 \mathrm{~m}$ above the mean sea level, with an average annual rainfall range of about $1613 \mathrm{~mm}$ per annum, annual mean temperature of about $27^{\circ} \mathrm{C}$ and average relative humidity of between 56 and $59 \%$ during the dry season, 51 - $82 \%$ during the wet season.

\section{Nursery Stage}

The nursery site was cleared of weeds and raised on beds to serve as support for the polythene pot. The site was sectioned into four layouts for each of the four treatments. Topsoils were collected and debris, stones pebbles and plant roots removed. Polythene pots of about $10 \mathrm{~cm} \times 18 \mathrm{~cm}$ in diameter and length with drainage holes were filled with the topsoil.

Source of planting materials

The different seeds/pods $\left(\mathrm{F}_{3}\right.$ amazon variety) were acquired from Cacao Research Institute of Nigeria (CRIN) Ibadan, Nigeria. The variety is a high yielding one commonly grown by farmers in the tropical rainforest zone of southwest Nigeria. Prepared Arbuscular mycorrhizae fungi (Glomus mossae) inoculum with soil as carrier was obtained from the International Institute of Tropical Agriculture (IITA), Ibadan Nigeria.

\section{Planting}

The seeds were sown in the filled polythene pots; one seed per pot and prior to planting the pots were watered. After planting, the pots were watered at 2days interval until germination (14-21days) was reached. Adequate watering was maintained thereafter to maintain good soil moisture condition. Minimal weeding was done and no disease incidence observed.

\section{Experimental Design}

The experiment was a randomized complete block design and the treatments replicated three times. Arbuscular mycorrhizae inoculant was applied at different levels $(25 \mathrm{~g}, 50 \mathrm{~g}$ and $100 \mathrm{~g}$ ) and un-inoculated Control. A total of 76 pots were inoculated with mycorrhizae, while 24 pots was un-inoculated (control), which gives a sum total of 90 pots of seedlings.

\section{Sampling and Data Collection}

Three plants from each treatment were randomly selected at the end of the experiment $(25 \mathrm{~g}, 50 \mathrm{~g}$ and $100 \mathrm{~g})$ and un-inoculated Control. Growth parameters taken fortnightly were plant height, number of leaf and stem girth. Harvested plants leaves, shoots and roots were collected and weighed to determine the fresh weight and then dried for few hours for the dry weight determination, these parameters were taken after termination of the experiment. The leaf area, plant dry and fresh weights were also used as a measure of growth using the classical growth analysis methods [7]. Relative mycorrhizal dependency (RMD) of cacao seedlings was calculated by expressing the difference between shoot dry weight 
of the mycorrhizal plant and the shoot dry weight of the non mycorrhizal plant as a percentage of the shoot dry weight of the mycorrhizal plant [15].

Mycorrhizal infection determination

Cacao seedling roots were collected from the inoculated replicates for mycorrhizal infection determination. It was grinded and stored in $50 \%$ ethanol. Mycorrhizal staining in the roots was achieved by heating the root samples in $10 \% \mathrm{KOH}$, rinsing with distilled water and soaking in $1 \% \mathrm{HCl}$ for 10 minutes. Trypan blue solution was used to stain the roots. The roots were soaked in the Trypan blue solution for 2 hours, and the stained roots were distained with $50 \%$ glycerol. The grid-intersect method of Giovanetti and Mosse [6] was used to evaluate the percentage of root infection.

\section{$\underline{\text { Statistical Analysis }}$}

The data collected were checked prior to statistical analysis and analyzed using analysis of variance (ANOVA) and means were separated using Tukey's test. SPSS $16^{\text {th }}$ edition statistical package was used for the analysis.

\section{RESULTS AND DISCUSSION}

As observed from the results Table 1, AMF inoculation generally effected significant changes in growth parameters recorded on cacao nursery seedlings at different levels of $25 \mathrm{~g}, 50 \mathrm{~g}$ and $100 \mathrm{galthough}$ significant differences were not observed between some treatments and the un-inoculated control.

Table 1: Effects of AMF inoculation on the growth parameters of cacao seedlings

\begin{tabular}{|l|l|l|l|l|l|l|l|}
\hline Treatment & $\begin{array}{c}\text { Plant } \\
\text { height } \\
(\mathbf{c m})\end{array}$ & $\begin{array}{c}\text { Leaf } \\
\text { number }\end{array}$ & $\begin{array}{c}\text { Stem } \\
\text { girth } \\
(\mathbf{m m})\end{array}$ & $\begin{array}{c}\text { Leaf } \\
\text { area } \\
\left(\mathbf{c m}^{\mathbf{3}}\right)\end{array}$ & $\begin{array}{c}\text { Fresh } \\
\text { shoot } \\
\text { weight } \\
\mathbf{( g )}\end{array}$ & $\begin{array}{c}\text { Fresh } \\
\text { root } \\
\text { weight } \\
\mathbf{( g )}\end{array}$ & $\begin{array}{c}\text { Total } \\
\text { fresh } \\
\text { biomass } \\
(\mathbf{g})\end{array}$ \\
\hline & & & $\mathbf{2 5 g}$ & & & & \\
\hline AMF & $28.33 \mathrm{ab}$ & $10.13 \mathrm{a}$ & $0.65 \mathrm{a}$ & $46.75 \mathrm{a}$ & $7.20 \mathrm{a}$ & $5.78 \mathrm{~b}$ & $12.98 \mathrm{a}$ \\
\hline & & & $\mathbf{5 0 g}$ & & & & \\
\hline AMF & $34.24 \mathrm{~b}$ & $11.70 \mathrm{a}$ & $0.67 \mathrm{a}$ & $51.38 \mathrm{a}$ & $7.42 \mathrm{a}$ & $6.48 \mathrm{~b}$ & $13.90 \mathrm{a}$ \\
\hline & & & $\mathbf{1 0 0 g}$ & & & & \\
\hline AMF & $37.89 \mathrm{~b}$ & $12.67 \mathrm{a}$ & $0.75 \mathrm{a}$ & $59.45 \mathrm{a}$ & $9.98 \mathrm{~b}$ & $6.77 \mathrm{~b}$ & $16.75 \mathrm{a}$ \\
\hline Control & $23.83 \mathrm{a}$ & $10.30 \mathrm{a}$ & $0.47 \mathrm{~b}$ & $41.50 \mathrm{a}$ & $6.11 \mathrm{a}$ & $3.73 \mathrm{a}$ & $9.84 \mathrm{~b}$ \\
\hline
\end{tabular}

*Means followed by similar letters are not significantly $(P<0.05)$ different according to Tukey's test

The results from the experiment agrees with result of past experiments in soil and soilless nursery systems where plants were inoculated with AMF e.g.; plant species such as in Eucalyptus camaldulensis [10], gladiolus [8], tomatoes [13] and palm species [12] who all reported that AMF inoculation produced 
significantly higher plant growth compared to the un-inoculated control. [13], also reported that arbuscular mycorrhiza fungi improved the qualities of seedlings in nurseries. No significant $(P<0.05)$ difference was observed in all treatments with respect to leaf number and leaf area, which plays important role in seedling growth and development, although cacao seedlings inoculated with $100 \mathrm{~g}$ of AMF exhibited higher statistical values of leaf number and leaf area compared to control and other treatments (Table 1). The fresh root weight was significantly higher in inoculated seedlings compared to un-inoculated control at $25 \mathrm{~g}, 50 \mathrm{~g}$ and $100 \mathrm{~g}$ rate of AMF inoculation, which will probably enhance uptake of nutrients and better growth in the field when transplanted. Significant difference was observed with respect to plant height in mycorrhized inoculated seedlings at $50 \mathrm{~g}$ and $100 \mathrm{~g}$, with higher statistical values of $(34.24 \mathrm{~cm}$ and $37.89 \mathrm{~cm}$ respectively) over the un-inoculated control $(23.83 \mathrm{~cm})$. Also the total fresh biomass weight of all inoculated cacao seedlings at different rates (12.98. 13.90 and $\left.16.75 \mathrm{~g} \mathrm{plant}^{-1}\right)$ were significantly different from the control $(9.84 \mathrm{~g}$ plant $^{-1}$ ), Similar trend was also observed in stem girth. This indicates that AMF inoculation on cacao seedlings irrespective of rates of application could efficiently promote higher vegetative growth of the seedlings.

In table 2, the shoot, root and total dry biomass of cacao seedlings increased significantly with AMF inoculation as compared to control at 50g and $100 \mathrm{~g}$ application.

Table 2: Effects of AMF inoculation on the dry biomass parameters and root/shoot ratio of cacao seedlings

\begin{tabular}{|l|l|l|l|l|}
\hline Treatment & $\begin{array}{c}\text { Shoot dry } \\
\text { weight }(\mathbf{g})\end{array}$ & \multicolumn{1}{|c|}{$\begin{array}{c}\text { Root dry } \\
\text { weight }(\mathbf{g})\end{array}$} & $\begin{array}{c}\text { Total dry } \\
\text { mass }(\mathbf{g})\end{array}$ & $\begin{array}{c}\text { Fresh } \\
\text { root/shoot } \\
\text { ratio }\end{array}$ \\
\hline & & $\mathbf{2 5 g}$ & & \\
\hline $\mathrm{AMF}$ & $2.37 \mathrm{~b}$ & $0.99 \mathrm{a}$ & $3.36 \mathrm{ab}$ & $0.80 \mathrm{a}$ \\
\hline & & $\mathbf{5 0 g}$ & & \\
\hline $\mathrm{AMF}$ & $3.17 \mathrm{a}$ & $1.17 \mathrm{a}$ & $4.34 \mathrm{a}$ & $0.87 \mathrm{a}$ \\
\hline & & $\mathbf{1 0 0 g}$ & & \\
\hline $\mathrm{AMF}$ & $3.88 \mathrm{a}$ & $1.21 \mathrm{a}$ & $5.09 \mathrm{a}$ & $0.69 \mathrm{a}$ \\
\hline Control & $2.22 \mathrm{~b}$ & $0.85 \mathrm{~b}$ & $3.07 \mathrm{~b}$ & $0.61 \mathrm{~b}$ \\
\hline
\end{tabular}

*Means followed by similar letters are not significantly different according to Tukey's test

The total dry biomass of AMF inoculated seedlings at rate of $50 \mathrm{~g}$ and $100 \mathrm{~g}$ application increased by $41.3 \%$ and $65.7 \%$ in comparison to the un-inoculated control, which will aid better performance in the field after transplanting. The statistical trends in fresh and dry root biomass were similar, being significantly higher in inoculated seedlings compared to un-inoculated seedlings. There was no significant difference observed in root/shoot ratio amongst the different treatments, but inoculated cacao seedlings had significantly higher root/shoot 
ratios over the un-inoculated seedlings (Table 2). According to [17], ability of seedlings to overcome transplanting shock depends on the capacity of the roots to support structural and functional changes, absorption of water and nutrients as well as the capacity of regenerating new roots. This agrees with the findings of [21] who reported that higher root/shoot ratio reflected a high degree of mycorrhizae effectiveness. The statistical value of mycorrhizae dependency (MD) recorded from shoot dry matter weight was $15.8 \%, 33.3 \%$ and $23.37 \%$ at the application rate of $25 \mathrm{~g}, 50 \mathrm{~g}$ and $100 \mathrm{~g}$ respectively in AMF inoculated seedlings and this indicates the seedlings growth response to AMF colonization. This result confirms the high dependency of cacao on mycorrhizae. Results in table 3, shows no AMF colonization was found on the roots of un-inoculated control seedlings, while in the inoculated seedlings the percentage root colonization was highest at 50g application $(81.4 \%)$.

Table 3: Effects of AMF inoculation on Mycorrhizal dependency, \% growth response and \% AMF Colonization of cacao seedlings

\begin{tabular}{|l|l|l|l|}
\hline Treatment & $\begin{array}{l}\text { Mycorrhizal } \\
\text { dependency }(\%)\end{array}$ & $\begin{array}{l}\text { Growth } \\
\text { response (\%) }\end{array}$ & $\begin{array}{l}\text { AMF Colonization } \\
\mathbf{( \% )}\end{array}$ \\
\hline AMF & & $\mathbf{2 5 g}$ & \\
\hline & $15.8 \mathrm{a}$ & $77.43 \mathrm{a}$ & $76.4 \mathrm{a}$ \\
\hline AMF & & $\mathbf{5 0 g}$ & \\
\hline & $33.3 \mathrm{a}$ & $84.13 \mathrm{a}$ & $81.4 \mathrm{a}$ \\
\hline AMF & & $\mathbf{1 0 0 g}$ & \\
\hline & & $75.00 \mathrm{a}$ & $71.5 \mathrm{a}$ \\
\hline Control & $23.37 \mathrm{a}$ & $0.00 \mathrm{~b}$ & $0.00 \mathrm{~b}$ \\
\hline
\end{tabular}

*Means followed by similar letters are not significantly different according to Tukey's test

However, it is important to note that high AMF infectiveness does not always guarantee an increase in plant growth [4]. Also growth response recorded in the experiment shows that AMF inoculated seedlings was significantly different from the un-inoculated seedlings.

\section{CONCLUSION}

This study reveals that AMF (Glomus mossae) promoted significant seedling growth and positively affected growth and development which resulted in higher biomass dry weight and root/shoot ratio with beneficial implications for improved cacao growth and yield when transplanted. Inoculated cacao seedlings at rate of $50 \mathrm{~g}$ and $100 \mathrm{~g}$ had better growth performance and responsiveness to AMF, hence it could be recommended to farmers in the tropical rainforest zone of south-west Nigeria for adoption. Therefore, application of AMF in cacao nursery could be an effective low input technology for improving growth and eventual yield on the field. 


\section{REFERENCES}

[1] "Cacao" Microsoft Encarta 2009 [DVD]. Redmond, WA.

[2] Adebiyi, S., Oluyole, K.A., Oduwole, O.O. and Famuyiwa, B.S. (2013). Farmer's attitude towards government initiative on cacao rehabilitation promotion in Oyo state, Nigeria. American Journal of Rural Development $1.115-18$

[3] Adenikinju, S.A, E.B. Esan and A.A. Adeyemi, (1989).Nursery Techniques, Propagation and Management of Cacao, Kola, Coffe, Cashew and Tea, Progress in Tree Crop Research, 2ndEdn., Cacao Research Institue, Ibadan Nigeria.

[4] Carpio, L.A., F.T. Davies and M.A. Arnold, (2005).Arbuscular mycorrhizal fungi, organic and inorganic controlled released fertilizers: Effect on growth and leachate of container grown bush morning glory (Ipomoea carnea ssp. fistulosa) under high production temperatures. J. American Soc. Hort. Sci., 130: 131-139

[5] Cacao Research Institute of Nigeria, (2002). Information Booklet; CRIN, Ibadan, Nigeria

[6] Giovanetti, M., Mosse B. (1980).An evaluation of techniques for measuring vesicular-arbuscular mycorrhizal infection in roots. New phytol 84,489 500.

[7] Hunt, R., (1982). Plant Growth Curves: the Functional Approach to Plant Growth Analysis. Edward Arnold, London

[8] Javaid, A. and T. Riaz, (2008) Mycorrhizal colonization in different varieties of gladiolus and its relation with plant vegetative and reproductive growth. Int. J. Agric. Biol., 10: 278-282

[9] Koide, R.T., (1991) Nutrient supply, nutrient demand and plant response to mycorrhizal infection. New Phytol., 117: 365-386

[10] Misbahuzzaman, K. and K. Ingleby, (2005). A structural study of ectomycorrhizae formed in Seedlings of Eucalyptus camaldulensis Dehnh. Int. J. Agric. Biol., 7: 400-405

[11] Opeke, L.K., (2003).Increasing cacao production in Nigeria during the third millennium. Ocassional Publication, No. 2, CAN, p: 24-32

[12] Ortas, I., Z. Kaya and I. Cakmak (2001). Influence of VA-Mycorrhiza inoculation on growth of maize and green pepper plants in phosphorus and zinc deficient soils. In: Horst, W.J., M.K. Schenk, A. Bürkert, N. Claassen, H. Flessa, W.B. Frommer, H.E. Goldbach, H.- W. Olfs, V. Römheld, B. Sattelmacher, U. Schmidhalter, S. Schubert, N. von Wirén and L. Wittenmayer. Plant Nutrition-Food Security and Sustainability of AgroEcosystems, pp: 632-633. Kluwer Akedmic Publishers, Dordrecht

[13] Oseni, T.O., N.S. Shongwe and M.T. Masarirambi (2010). Effect of arbuscular mycorrhiza (AM) inoculation on the performance of tomato nursery seedlings in vermiculite. Int. J. Agric. Biol., 12: 789-792 
[14] Pfleger, F.L. and R.G. Linderman, (1994). Mycorrhizae and plant health. In:Pfleger, F.L. and R.G. Linderman (eds.), Mycorrhizae and Plant Health, pp: 337-344. APS Press, St. Paul, Minnesota

[15] Plenchette, C., J.A. Fortin and V. Furlan, (1983). Growth responses of several plant species to mycorrhizae in a soil of moderate P fertility. I. Mycorrhizal dependency under field conditions. Plant Soil, 70: 199-209

[16] Ryan, M.H. and J.F. Angus, (2003). Arbuscular mycorrhizae in wheat and field pea crops on a low P soil: increased $\mathrm{Zn}$-uptake but no increase in $\mathrm{P}$ uptake or yield. Plant Soil, 250: 225-239

[17] Scagel, C.F., (2004).Isolate-specific rooting responses of Leucothoe fontanesiana cuttings to inoculation with ericoid mycorrhizal fungi. J. Hort. Sci. Biotech., 80: 252-262

[18]Sgrott, A.F., Booz, M.R., Pescador, R., Heck, T.C. and Sturmer, S.L. (2012).Arbuscular mycorrhizal inoculation increases biomass of Euterpeedulis and Archontophoenix alexandrae after two years under field conditions. Rev. Bras. Cienc. Solo vol 36 no. 4 Vicosa July/Aug. 2012

[19] Smith, S.E. and D.J. Read (1997).Vesicular-Arbuscular Mycorrhizas. In:Smith, S.E. and D.J. Read (eds.), Mycorrhizae, pp: 9-61. Academic Press, London

[20] Steve, N. and Lane, G. (2001). Review on the use of NPK Fertilizers on cacao seedlings in the Nursery. 3Ed. Academia Press, London

[21] Tobar, R.M., R. Azcon and J.M. Barea (1999). The improvement of plant N acquisition from an ammonium treated drought stressed soil by the fungal symbionts in Arbuscular mycorrhizae. Soil Biol. Fert., 9: 1-8 